\title{
Translation Criticism of Ecological Terms in Environmentally Oriented Literary Work Baraumi Shougakkou by Miyazawa Kenji
}

\author{
Lina Rosliana ${ }^{1}$, Elizabeth Ihan Rini ${ }^{2}$, Zaki Ainul Fadli ${ }^{3}$, and Dewi Kusmiati ${ }^{4}$ \\ ${ }^{1}$ Diponegoro University, Japanese and Culture Department, Semarang, Indonesia \\ ${ }^{2}$ Diponegoro University, Japanese and Culture Department, Semarang, Indonesia \\ ${ }^{3}$ Diponegoro University, Japanese and Culture Department, Semarang, Indonesia \\ ${ }^{4}$ Diponegoro University, Japanese and Culture Department, Semarang, Indonesia
}

\begin{abstract}
Baraumi Shougakkou is a children's short story written by Miyazawa Kenji, a famous writer for producing literary works covering all the natural elements in the world; humans, animals, plants, rocks, wind, clouds, light, stars, and the sun. His works have been translated into many languages, including Indonesian. However, in translating a literary work, there are several issues, one of which is translating ecological terms. It needs the proper method so that the ecological terms can be translated accurately and provide a common perception between the readers of the original work and the readers of the translated works. This study aims to analyze the translation of ecological terms in environmentally oriented work Baraumi Shougakkou by Miyazawa Kenji. This study uses literature study methods from various sources as primary and secondary references related to translation criticism. Ecology, such as flora, fauna, geography, climate, is difficult to find the equivalents in translation. Baraumi Shougakkou translation uses several Newmark translation procedures, such as literal and paraphrases, that can provide translation results that are close to the target language.
\end{abstract}

\section{Introduction}

Humans are always motivated to produce a work such as literature with their creativity, taste, and intention. There are several genres of literary works, one of which is fiction. Fiction can be interpreted as narrative prose that is imaginary but usually makes sense and contains the truth that dramatizes human relationships [1]. A work of fiction is a work that tells something fictional, imaginary, something that does not exist and happens, so there is no need to find the truth in the real world [2].

* Corresponding author: linarosliana@lecturer.undip.ac.id. 
Baraumi Shougakkou is a fictional story by Miyazawa Kenji, a children's story writer who is famous for producing many inspiring works. His works have been translated into many languages, including Indonesian. Baraumi Shougakkou was translated into Indonesian by the Center for Japanese Studies (PSBJ) staff in collaboration with The Japan Foundation in 1996.

Baraumi Shougakkou is a short story that tells the main character "I" to go on an adventure looking for volcanic rock and plant named Hamanasu. Hamanasu is a coastal plant that can grow in grasslands. In his adventure, the character "I" finds a unique school of foxes. The school teaches various disciplines, such as Ethics and Martial Arts, Hunting Engineering, and Food Chemistry. Although this short story is an imaginary story, many ecological terms and scientific vocabulary need special attention when translating them into foreign languages. Translating Miyazawa Kenji's works is certainly a challenge in itself because the stories are rich in elements of ecology, mimesis, dialects, word plays to the names of characters who have certain symbols [3]. This research is expected to be a pioneer and play a role in formulating issues in translating Japanese literary works into Indonesian. This study aims to discuss the translation procedures in translating Baraumi Shougakkou's short story and examine the equivalence of ecological terms in the source text with the target text

\subsection{Translation}

The term translation is commonly understood as follows: transforming a text written in one language (source language, SL) into an "equivalent" text in a different language (target language, TL), retaining the meaning and functional roles of the original text. The original text in the SL is called a source text (ST), and the product of translation is called a target text (TT). [4] The term translation is used to refer either to the process of translation or its end product or sometimes to a more abstract concept encompassing both. Translation can be written or spoken; oral translation is called interpreting. (Sometimes, the term interpretation is also used, but all translation involves an act of interpretation, and thus the term is ambiguous.) [5]

Nida and Taber, in their book, The Theory, and Practice of Translation [6], say that translation activities focus on two things. First, translation is more concerned with form and style; second, translation is more concerned with the readers' response who receive the translation results. The focus of this translation is associated with dynamic equivalents. If the reader's response to the source text (ST) of the target text (TT) is the same, then the translation is considered a dynamic equivalent.

From the two definitions above, we can conclude that translation means re-expressing the same meaning by using the appropriate lexicon and grammatical structure in the target language by paying attention to various contexts so that the orientation of the original text reader is the same as that of the translated text reader.

\subsection{Translation Criticism}

Translation criticism is an essential link between translation theory and its practice [7]. Newmark argues that a translator must have a principle or ideology before making translation criticism. After that, five stages must be considered when criticizing translation, namely (1) text analysis; (2) the translators' purpose; (3) comparing the translation with the original; (4) the evaluation of the translation; (5) an assessment of the likely place of the translation in the target language (TL) culture or discipline.

According to Newmark [8]. When conducting a translation criticism, two things need to be considered from the translation results, namely referential and linguistics mistakes. Referential mistakes are about facts, the real world, propositions, not words. Statements like 
'water is air' 'water is black ' ' water breathes' are referential mistakes (though as metaphors, they may be profoundly true). Referential mistakes exist in 'fiction' (i.e., imaginative literature) only when it incorrectly depicts the real world now or in history. They reveal the ignorance of the translator, or worse, of the writer, which the translator has 'copied'. Linguistic mistakes show the translator's ignorance of the foreign language: they may be grammatical or lexical, including words, collocations, or idioms.

\section{Method}

This research is a qualitative descriptive study. The researchers try to describe in-depth the translation procedures and the equivalence in translating Miyazawa Kenji's short story Baraumi Shougakkou into Indonesian. This research model is a translation criticism that raises specific matters, focusing on equivalence and translation procedures by describing data representing phenomena in-depth. The research stages include data collection, classification, and analysis.

\section{Results and Discussion}

\subsection{Translation Procedures}

While translation methods relate to whole texts, translation procedures are used for sentences and the smaller units of language [9]. There are several translation procedures, including:

1. Transference

Transference is the process of transferring a SL word into a TL as a translation procedure. The result of this procedure is a loanword. This procedure can be performed if none of the TL equivalents is deemed adequate. The loan word is concise and emphasizes the culture of the SL message because the translator's job is to explain, bring out what is unique and exotic in TL.

2. Cultural Matching

Cultural matching is carried out if SL has an equivalent in a word containing culture in TL. However, this matching can lead to certain deviations because such translations are minimal, and none are entirely accurate.

3. Descriptive Translation

Descriptive translation is translating by combining functional equivalents and descriptive equivalents, namely explaining words with several words.

4. Naturalization

Naturalization is a way to adapt a word from SL to standard pronunciation and then to TL's typical morphological structure.

5. Meaning Component Analysis

The meaning component analysis is carried out by comparing the general and specific components of SL and TL to find a translation closer to TL, even though the word in SL certainly has a more specific meaning.

6. Combinations

Combinations are generally used by combining two translation procedures to get an equivalent translation.

7. International Standard Translation

This procedure uses a vocabulary translation that has been agreed upon internationally.

8. Paraphrase; glossary; footnote

This method explains hidden meanings by decomposing a speech into another form or arrangement of words. 


\subsection{Translation Equivalence}

Newmark defines culture as the way of life and its manifestations peculiar to a community that uses a particular language as its means of expression. Language, however, contains all kinds of cultural deposits in the grammar (genders of inanimate nouns), forms of address, and the lexis, which are not taken into account in universal either in consciousness or translation. Further, the more specific a language becomes for natural phenomena (e.g., flora and fauna), the more it becomes embedded in cultural features, creating translation problems [10].

Nida and Taber [11] state that five things are challenging to find their equivalence in the translation process: ecology, material culture, religious terms, social structures, and language. More specifically, Newmark [12] states that things that are difficult to find equivalents in translation relate to:

1. Ecology

Flora, fauna, winds, plains, hills.

2. Material culture (artefacts)

Food, clothes, houses and towns, transport.

3. Social culture - work and leisure

4. Organizations, customs, activities, procedures, concepts

Political and administrative, religious.

According to Nida and Taber [13], translation equivalences can be grouped into two groups, namely:

1. Formal equivalences are equivalences that focus on presenting as much form and content as possible from the original text of the source language.

2. Dynamic equivalent is the equivalent that prioritizes the equivalent effect on the receiver and the equivalent response of the Target Language user.

\subsection{Translating Ecological Terms in Baraumi Shougakkou's Short Story}

The Ecological Society of America (ESA) defines ecology as studying the relationships between living organisms, including humans, and their physical environment; it seeks to understand the vital connections between plants and animals and the world around them. Ecology includes the study of plant and animal populations, plant and animal communities, and ecosystems. Therefore, in our daily life, we often come into contact with terms that belong to the field of ecology.

The short story of Baraumi Shougakkou is Miyazawa Kenji's work written when he was a teacher at the Aso agricultural school. Many of his works had the theme of the relationship between humans, flora, fauna, and the environment. Baraumi Shougakkou contains at least 30 kinds of ecological terms, such as mountains, beaches, volcanoes, plants, weeds, clumps, springs, shoots, clouds, sun, wind, foxes, wolves, chickens, birds. Some of the words among these ecological terms have specific names in Japanese, such as hamanasu plant, katabira suzume grass, awa, barakubo cypress. These words require special attention in their translation. Following are the analysis of the translation procedures and the equivalence of ecological terms in Baraumi Shougakkou's short story into Indonesian.

\subsubsection{Procedure for Translating Ecological Terms in Baraumi Shougakkou}

1. Transference

Transference (emprunt, loan word, transcription) transfers an SL word to a TL text as a translation procedure. The word then becomes a 'loan word'. In Baraumi Shougakkou, 
there is an ecological term translated into this procedure because of the difficulty of finding the equivalent of the term in Indonesian.

Baraumi nohara is translated into Indonesian as 'padang Baraumi' (field; plains; prairie called Baraumi). Although Baraumi can be translated based on the kanji that forms it, namely ibara (thorn) and umi (sea), the translator does not translate it into a sea of thorns. Baraumi is retained because it is considered the name of a field and the name of a school in the area.

The same procedure is carried out for the term suzume no katabira which translates to 'rumput suzume katabira' (katabira grass). Hamanasu which translates to 'tanaman hamanasu' (hamanasu plant). Susuki translates to 'ilalang susuki' (susuki thatch), barakubo no matsubayashi translates to 'cemara barakubo' (barakubo) spruce). 'Jawawut awa' are only translated awa (millet).

2. Analysis of the Meaning Components

This translation procedure is carried out if the term in the source language has a specific meaning that has no equivalent in the target language. It is generally translated with the closest word.

Shiroi urogo kumo (white urogo cloud) translates to 'awan putih' (white cloud), yasei (wild plant) translates to 'tanaman' (plant), 'kaya' (a kind of bud) translates to 'tunas' (shoots).

3. Paraphrase

The paraphrasing procedure is a way out when translating. With this technique, words or sentences that are difficult to understand can be deciphered again with other forms so that their meaning is easier to understand.

Daigaku no rinka denotes a high school in which it has a special department that studies forestry. However, in Baraumi Shougakkou the translator wisely translates it into 'Universitas Kehutanan' (Forestry University). This term is more uncomplicated for Indonesian reader to understand without changing the true meaning of the source text.

4. The Other Translation Procedures

The translation of ecological terms in the short story Baraumi Shougakkou also uses a literal translation procedure for words that are often used in everyday life, such as sun, wind, sky, beach, corn, wheat, cabbage, chicken, bird, fox, wolf, caterpillar, water springs.

\subsubsection{The equivalent of the term ecology in the translation of the short story Baraumi Shougakkou}

Most of the translations of the term ecology in Baraumi Shougakkou's short stories have dynamic equivalents. The translation of form and meaning prioritizes closeness to the target text reader. However, for ecological terms related to plant names and place names, the translator uses a formal equivalent because it is difficult to find the equivalent of the term in Indonesian.

\section{References}

1. B. Nurgiyantoro, Teori Pengkajian Fiksi, (Gadjah Mada University Press Yogyakarta, 1994)

2. L. Rosliana, Konsep Filsafat Pendidikan dalam Cerpen “Baraumi Shougakkou” Karya Miyazawa Kenji Melalui Pendekatan Hermeneutik, Thesis, (2004)

3. L. Rosliana, Konsep Filsafat Pendidikan dalam Cerpen "Baraumi Shougakkou” Karya Miyazawa Kenji Melalui Pendekatan Hermeneutik, Thesis, (2004) 
4. Y. Hasegawa. The Routledge Course in Japanese translation, (Routledge London and New York, 2012)

5. P. Newmark, Text Book of Translation, (Pretice Hall New York, 1988)

6. E. A. Nida, C. R. Taber, The Theory and Practice of Translation, (1974)

7. P. Newmark, Text Book of Translation, (Pretice Hall New York, 1988)

8. P. Newmark, Text Book of Translation, (Pretice Hall New York, 1988)

9. P. Newmark, Text Book of Translation, (Pretice Hall New York, 1988)

10. P. Newmark, Text Book of Translation, (Pretice Hall New York, 1988)

11. E. A. Nida, C. R. Taber, The Theory and Practice of Translation, (1974)

12. P. Newmark, Text Book of Translation, (Pretice Hall New York, 1988)

13. E. A. Nida, C. R. Taber, The Theory and Practice of Translation, (1974) 